MINIREVIEWS

\title{
The mechanisms of activation of the single chain cytokine receptors: preformed and ligand-induced dimerization
}

\author{
V. S. Gryshkova ${ }^{1,2}$, R. I. Albu ${ }^{3}$, S. N. Constatinescu ${ }^{1,2}$ \\ ${ }^{1}$ Ludwig Institute for Cancer Research \\ Avenue Hippocrate 74, Brussels B1200, Belgium \\ ${ }^{2}$ Universite catholique de Louvain, de Duve Institute \\ Avenue E. Mounier 53, Brussels B1200, Belgium \\ ${ }^{3}$ Cliniques universitaires Saint-Luc \\ Avenue Hippocrate 10, Brussels B1200, Belgium \\ vitalina.gryshkova@bru.licr.org
}

\begin{abstract}
Despite intensive studies, the mechanisms of cytokine receptor activation are still not completely understood. Historically two models have been proposed: early studies suggested a mechanism involving ligand-induced dimerization of the receptors which results in the activation of downstream signaling pathways, whereas, in the absence of ligands, the receptors are thought to be in a monomeric inactive state; later studies uncovered evidence for the existence of many receptors as inactive preformed dimers, which upon ligand binding undergo conformational changes and/or relative rotation of the receptor molecules. Here we focus on the dimerization status of the single chain cytokine receptors, which are involved in the regulation of hematopoiesis.
\end{abstract}

Keywords: cytokine receptors, dimerization, hematopoiesis.

Cytokine receptor family. Cytokines are a large group of polypeptide growth factors that bind to their cognate receptors and mediate intracellular signaling events leading to the modulation of gene expression. Most cytokine receptors consist of a multi- or disubunit complex: a unique and specific ligand-binding chain and a signaltransducing subunit, which may be structurally similar to other members of the cytokine receptor superfamily $[1,2]$. Type I cytokine receptors can be organized into subgroups by the number of receptor subunits and the use of common signaling chains: single chain family of the receptors; the common $\beta$ chain $(\beta c)$ family; gp130 family and the common $\gamma$ chain $(\gamma c)$ family (Fig. 1). Type II cytokine receptors are always heterodimers and include interferon receptors. The single chain cytokine receptor subfamily includes receptors for growth hormone $(\mathrm{GH})$, prolactin (PRL), erythropoietin (EPO), granu-

(C) Institute of Molecular Biology and Genetics, NAS of Ukraine, 2014 locyte-colony-stimulating factor (GCSFR) and thrombopoietin (TpoR). These receptors share some common structural features: cytokine receptor homology domain (CRH) which can be divided into two sub-domains of approximately 100 amino acids (namely D1 for N-terminal part) and the membrane distal sub-domain (namely D2); WSXWS motif at the C-end of D2 domain, which was shown to be important for the folding and traffic of the receptors; Box1 (proline-rich motif) and Box2 (hydrophobic part) in the intracellular domain of the receptors are conserved and important for JAK2 binding and signal transduction [3-6] (Fig. 1).

Cytokine receptors lack intrinsic kinase activity and rely on the activation of cytoplasmic Janus kinase (JAKs) family proteins that are recruited onto their intracellular domains [7]. Cytokine binding to the receptor extracellular domain elicits a conformational change which rearranges the preformed dimers or promotes the dimer or oligomer formation from monomeric chains 


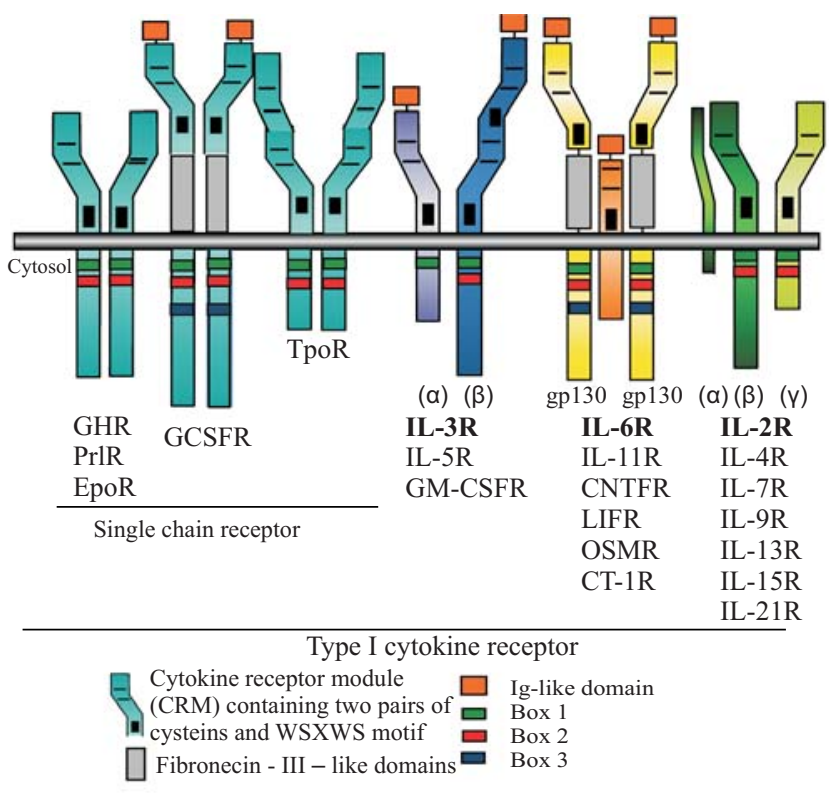

Fig. 1. Schematic representation of type I cytokine receptors subgroups

[8]. This conformation is transmitted to the cytosolic juxta-membrane receptor domain, which brings into close proximity the active and catalytic loops of JAKs enabling them to trans-phosphorylate and activate each other [9]. The activated JAKs phosphorylate the tyrosine residues on receptor cytosolic tails, which recruit several signaling substrates, including, in the first place, the members of the signal transducer and activator of transcription (STAT) family [10].

Since conformational changes in pre-formed dimer or dimerization of two monomer subunits by ligand are two most probable mechanisms of the receptor activation, application of different techniques is important for the investigation of cytokine receptors dimerization. Table briefly summarizes different techniques, which were applied to study dimerization of single chain cytokine receptors.

Growth Hormone Receptor (GHR). GH is the major regulator of postnatal growth. GH binds to its receptor (GHR) providing somatogenic, metabolic and differentiative effects. GHR was the first receptor of class 1 cytokine receptors to be cloned. The crystal structures of the bound and unbound forms have been solved suggesting that two receptor subunits bind one molecule of hormone [11]. Two distinct sites within GH molecule engage two GHR extracellular domains at nearly iden- tical contact points on each receptor [11]. Studies on human GHR by co-immunoprecipitation of differently epitope-tagged receptors showed that GHR exists as a ligand-independent dimer [12]. Further studies using fluorescence resonance energy transfer (FRET) and bioluminescence resonance energy transfer (BRET) confirmed that the receptor subunits undergo specific transmembrane interaction independent of hormone binding. An activation mechanism was proposed where the change of conformation in pre-formed dimer activates downstream signaling in response to the hormone binding $[13,14]$. Binding of the hormone to the preformed GHR dimer realigns two receptor subunits by rotation and closer apposition, followed by a juxtaposition of the catalytic domains of the associated tyrosineprotein kinase JAK2 below the cell membrane. Atomistic molecular dynamics simulations have been used to explore the conformational changes linked to the binding of human growth hormone (hGH) to the extracellular domains of the human growth hormone receptor (hGHR) suggesting that hormone binding induces the GHR subunit rotation [15]

Prolactin Receptor (PrIR). Prolactin was first shown to stimulate lactation during pregnancy and mammary gland development, but further investigations have proven it to be important in the water and electrolyte balance, growth and development, metabolic functions, immunoregulation and also some neuroendocrine functions [16]. Unlike GHR, where one gene encodes a single transcript, several isoforms of PrlR are generated by alternative splicing [17]. The structure of the extracellular domains of these isoforms appeared to be identical but the length of intracellular domains different. Similar to GHR, two PrlRs have been proven to bind one Prl molecule by engaging two different sites. The Prl molecule was believed to first recruit one PrlR monomer through its binding site 1 , thus forming an inactive complex, followed by the addition of another receptor monomer to the binding site 2 of the ligand and activate the complex.

However, the later studies showed that PrlR existed as a preformed dimer on cell membranes, but receptor predimerization is insufficient to trigger signaling in the absence of a ligand $[18,19]$. Only upon ligand binding, the receptor undergoes a conformational change to activate the downstream signaling pathways. The structure 
Techniques applied to study the dimerezitaion of single chain cytokine receptors

\begin{tabular}{ccc}
\hline Assays applied & Receptor studied & Reference \\
\hline $\begin{array}{c}\text { Co-immunoprecipitation } \\
\text { Co-Patching }\end{array}$ & GHR, PrlP & {$[12,18]$} \\
$\begin{array}{c}\text { Structural studies (NMR, } \\
\text { crystallography) }\end{array}$ & GHR, PrlR, & {$[11,19,20,22$,} \\
$\begin{array}{c}\text { GSFR, EpoR } \\
\text { Sedimentation equilibrium } \\
\text { analytical ultracentrifugation }\end{array}$ & EpoR, TpoR & {$[50,36]$} \\
TOXCAT & TpoR & {$[49]$} \\
$\begin{array}{c}\text { FRET (Foster Resonance } \\
\text { energy Transfer) }\end{array}$ & GHR & {$[13]$} \\
$\begin{array}{c}\text { BRET (Bioluminescence } \\
\text { Resonance energy transfer) }\end{array}$ & GHR, PrlR & {$[13,19]$} \\
Cross-linking & TpoR & {$[53]$} \\
$\begin{array}{c}\text { Complementation of } \\
\text { dihydrofolate reductase } \\
\text { Gaussia princeps luciferase } \\
\text { complementation }\end{array}$ & EpoR, TpoR & {$[39]$} \\
\hline
\end{tabular}

of 2:1 complex between the ECD of two rat PrlR and the human Prl was solved in 2010 [20].

Granulocyte-Colony-Stimulating Factor Receptor. GCSFR, or as it has recently been renamed, CSF3R, the main hematopoietic growth factor that controls neutrophil development. Besides, GCSF plays an important part in the so-called «emergency granulopoiesis» by enhancing the numbers and functions of the neutrophils in response to bacterial infections. Both effects are accomplished by inducing the proliferation and survival of the myeloid precursors, followed by a cell cycle arrest and neutrophilic differentiation [21]. The crystal structure of a 2:2 complex involving human GCSF and the CRM domain of mouse GCSFR has been published in 1999 [22]. Although this structure revealed a significant information concerning the ligand-receptor interactions, it failed to clarify the mechanism of the receptor activation, as the complex did not contain the original Ig-like domain normally present in the receptor. In 2005, the crystal structure of a complex between hGCSF and the Ig-like and CRM (Ig-CRM) domains of human GCSFR (hGCSFR) at 2.8-A resolution was reported [23]. The 2:2 receptor:ligand signaling complex was obtained by using crossover interactions involving the Ig-like do- main of hGCSF-R and the neighboring hGCSF, in a twofold axis of crystallographic symmetry. This structure is rather distinct from that of the heterogeneous mouse GCSF-R complex [22] resembling more closely the 2: $2: 2$ active complex of human interleukin-6, hIL-6 receptor and human gp130 (the last cytokine receptor is a shared signal transducing unit for several cytokines) [24], and the 2:2 assembly of viral IL-6 and human gp130 [25], rather than the other homodimeric receptors of its subgroup. The Ig-like domain crossover conformation required for GCSFR activation was in agreement with the earlier reports based on the mutational and thermodynamic analyses [26].

Erythropoietin receptor (EpoR). Epo together with its receptor (EpoR) are involved in the production of erythrocytes [27]. Epo or EpoR knock-out mice die at embryo day 12,5 of severe anaemia [28]. However, the recent studies highlighted additional roles of Epo and its receptor in non-hematopoietic processes such as angiogenesis and wound healing [29, 30]. Dimerization of the receptor was highlighted as an important feature of the EpoR activation mechanism. The most studied phenomenon that supports this observation is the constitutively active EpoR mutant, which has a point substitution of arginine to cysteine (EpoR R129C) in the extracellular domain, which was shown to induce intermonomeric disulfide bond formation and activation [31].

The studies of EpoR dimerization by bivalent antibodies against the EpoR extracellular domain [32], or Epo-mimetic peptides [33], analysis of chimeric receptor molecules [34] or by employing biochemical studies of the purified EpoR extracellular region [35] supported the idea that receptor homodimerization is an important step in the activation process. The data supporting this idea were also obtained from the 3-dimensional structure analyses of the EpoR extracellular region bound to the Epo or erythropoietic peptide agonists. The EpoR:Epo complex is a dimeric receptor occupied by a single Epo molecule in a 2:1 ratio [36,37]. Fulllength EpoR on the cell surface was shown to be a preformed dimer as well as short forms of EpoR [38, 39]. Mainly the transmembrane domain mediates dimerization of EpoR in the absence of ligand [38]. The study of the Epo:EpoR complex revealed that Epo has 2 discrete binding sites in EpoR with different affinities to Epo [40]. Thus, Epo binds asymmetrically to EpoR dimer. 
Thrombopoiein receptor (TpoR). Thrombopoietin and its receptor, $\mathrm{Mpl}$ (TpoR), are the primary regulators of megakaryocytopoiesis and play a critical role in the hematopoietic stem biology [41, 42]. Upon ligand binding, Mpl facilitates tyrosine phosphorylation of cytoplasmic signaling proteins and activation of several signaling pathways, including JAK-STAT, MAPK and PI3K $[43,44]$. TpoR is a major regulator of megakaryopoiesis and platelet formation, but is also required for maintaining the quiescence of hematopoietic stem cells, regulating proliferation of early myeloid progenitors $[45,46]$. The structural modelling and ligand binding affinity experiments showed that first 280 amino acids of the extracellular domain of TpoR are responsible for the Tpo binding and possibly for preventing the rest of the receptor from signaling in the absence of the ligand [47]. The crystal structure of any extracellular part of TpoR is not available so far. Nevertheless, the crystal structure of the receptor-binding domain of human Tpo coupled with a neutralizing Fab fragment was solved in 2004 [48].

The experiments using titration calorimetry showed that human Tpo interacts with soluble Tpo receptor containing the extracellular cytokine receptor homology domains in 1:2 stoichiometry.

Therefore, the model for the activation of TpoR is similar to other single chain receptors. Resent studies confirmed that the transmembrane domain of TpoR and full length TpoR form homodimers in a ligand-independent manner $[49,50]$, although at lower levels than EpoR.

Most of the studies showed that single chain receptors on the plasma membrane form dimers before ligand binding. This implies that conformational changes are required in preformed dimers to activate downstream signaling upon ligand binding. However, it could not be excluded, that the receptors exist in monomeric and dimeric forms on the cell surface and the ligand could bind to both of them at the same time promoting complex activation. The equilibrium might exist between monomeric and dimeric forms, and high levels of expression might displace the equilibrium towards the dimeric form. What appears certain is that even at high expression levels and near-complete ligand-independent dimerization, the receptors are designed to remain inactive in the absence of cytokine stimulation.
Full understanding of the cytokine receptor activation is a major challenge for the future, as well as application of new techniques to investigate the dimerization issue.

Механізми активації мономерних рецепторів цитокінів: ліганд-незалежна та ліганд-індукавана димеризація

В. С. Гришкова, Р. І. Албу, С. Н. Константинеску

Резюме

Незважаючи на інтенсивні дослідження, механізми активації цุитокінових рецепторів наразі є не зовсім зрозумілими. Історично було запропоновано дві моделі: у ранніх роботах припускали механізм ліганд-індукованої димеризації рецепторів, щчо призводить до активачії більш пізніх сигнальних иляхів, у той час як за відсутності лігандів рецептори перебувають у мономерому неактивованому стані; подальшими дослідженнями виявлено докази існування багатьох рецепторів у формі неактивованих сформованих димерів, які при зв'язуванні ліганда зазнають конформаційних змін та/або мономери яких починають ротаційно переміщуватися відносно один одного. Даний огляд сфокусовано на проблемі димеризачї окремих гомодимерних рецепторів цитокінів, які причетні до регулячії кровотворення.

Ключові слова: рецептори иитокінів, димеризачія, гематопоез.

Механизмы активации мономерных рецепторов цитокинов: лиганд-независимая и лиганд-индуцированная димеризация

В. С. Гришкова, Р. И. Албу, С. Н. Константинеску

Резюме

Несмотря на интенсивные исследования, механизмы активации цитокиновых рецепторов до сих пор не полностью изучены. Исторически было предложено две модели: ранние работы предполагали механизм лиганд-индуичированной димеризации рецепторов, что приводит к активации более поздних сигнальных путей, в то время как при отсутствии лигандов речепторы находятся в мономерном неактивном состоянии; последующие исследования выявили доказательства существования многих рецепторов в форме неактивированных сформированных димеров, которые при связывании лиганда претерпевают конформационные изменения и/или мономеры которых начинают ротационно перемещаться относительно друг друга. Данньй обзор сфокусирован на проблеме димеризации отдельных гомодимерних рецепторов ичитокинов, вовлеченнх в регулячию кроветворения.

Ключевые слова: речепторы иитокинов, димеризаиия, гематопоез.

\section{REFERENCES}

1. Hunter T. Signal transduction. Cytokine connections. Nature. 1993; 366(6451):114-6.

2. Baker SJ, Rane SG, Reddy EP. Hematopoietic cytokine receptor signaling. Oncogene. 2007;26(47):6724-37.

3. Bazan JF. Haemopoietic receptors and helical cytokines. Immunol Today. 1990;11(10):350-4. 
4. Bazan JF. Structural design and molecular evolution of a cytokine receptor superfamily. Proc Natl Acad Sci USA. 1990;87(18): 6934-8.

5. Witthuhn BA, Quelle FW, Silvennoinen O, Yi T, Tang B, Miura $O$, Ihle $J N$. JAK2 associates with the erythropoietin receptor and is tyrosine phosphorylated and activated following stimulation with erythropoietin. Cell. 1993;74(2):227-36.

6. Quelle FW, Sato N, Witthuhn BA, Inhorn RC, Eder M, Miyajima $A$, Griffin $J D$, Ihle $J N$. JAK2 associates with the beta c chain of the receptor for granulocyte-macrophage colony-stimulating factor, and its activation requires the membrane-proximal region. Mol Cell Biol. 1994;14(7):4335-41.

7. Ihle JN, Kerr IM. Jaks and Stats in signaling by the cytokine receptor superfamily. Trends Genet. 1995;11(2):69-74.

8. Stroud RM, Wells JA. Mechanistic diversity of cytokine receptor signaling across cell membranes. Sci STKE 2004;2004(231):re7.

9. Behrmann I, Smyczek T, Heinrich PC, Schmitz-Van de Leur H, Komyod W, Giese B, Muller-Newen G, Haan S, Haan C. Janus kinase (Jak) subcellular localization revisited: the exclusive membrane localization of endogenous Janus kinase 1 by cytokine receptor interaction uncovers the Jak receptor complex to be equivalent to a receptor tyrosine kinase. J Biol Chem. 2004;279(34): 35486-93.

10. Darnell JE Jr., Kerr IM, Stark GR. Jak-STAT pathways and transcriptional activation in response to IFNs and other extracellular signaling proteins. Science. 1994;264(5164):1415-21.

11. de Vos AM, Ultsch M, Kossiakoff AA. Human growth hormone and extracellular domain of its receptor: crystal structure of the complex. Science. 1992;255(5042):306-12.

12. Gent J, van Kerkhof P, Roza M, Bu G, Strous GJ. Ligand-independent growth hormone receptor dimerization occurs in the endoplasmic reticulum and is required for ubiquitin system-dependent endocytosis. Proc Natl Acad Sci USA. 2002;99(15):9858-63.

13. Brown RJ, Adams JJ, Pelekanos RA, Wan Y, McKinstry WJ, Palethorpe K, Seeber RM, Monks TA, Eidne KA, Parker MW, Waters MJ. Model for growth hormone receptor activation based on subunit rotation within a receptor dimer. Nat Struct Mol Biol. 2005;12(9):814-21.

14. Yang N, Wang X, Jiang J, Frank SJ. Role of the growth hormone $(\mathrm{GH})$ receptor transmembrane domain in receptor predimerization and GH-induced activation. Mol Endocrinol. 2007;21(7): $1642-55$.

15. Poger D, Mark AE. Turning the growth hormone receptor on: evidence that hormone binding induces subunit rotation. Proteins. 2010;78(5):1163-74.

16. Bernichtein $S$, Touraine P, Goffin $V$. New concepts in prolactin biology. J Endocrinol. 2010;206(1):1-11.

17. Trott JF, Hovey RC, Koduri S, Vonderhaar BK. Alternative splicing to exon 11 of human prolactin receptor gene results in multiple isoforms including a secreted prolactin-binding protein. $J$ Mol Endocrinol. 2003;30(1):31-47.

18. Gadd SL, Clevenger CV. Ligand-independent dimerization of the human prolactin receptor isoforms: functional implications. $\mathrm{Mol}$ Endocrinol. 2006;20(11):2734-46.

19. Qazi AM, Tsai-Morris CH, Dufau ML. Ligand-independent homo- and heterodimerization of human prolactin receptor variants: inhibitory action of the short forms by heterodimerization. $\mathrm{Mol}$ Endocrinol. 2006;20(8):1912-23.

20. van Agthoven J, Zhang C, Tallet E, Raynal B, Hoos S, Baron B, England P, Goffin V, Broutin I. Structural characterization of the stem-stem dimerization interface between prolactin receptor chains complexed with the natural hormone. J Mol Biol. 2010 401(1):112-26.

21. Demetri GD, Griffin JD. Granulocyte colony-stimulating factor and its receptor. Blood. 1991;78(11):2791-808.

22. Aritomi M, Kunishima N, Okamoto T, Kuroki R, Ota Y, Morikawa $K$. Atomic structure of the GCSF-receptor complex showing a new cytokine-receptor recognition scheme. Nature. 1999; 401 (6754):713-7.

23. Ishibashi $M$, Tokunaga H, Arakawa T, Tokunaga $M$. Expression, purification, and characterization of the active immunoglobulin-like domain of human granulocyte-colony-stimulating factor receptor in Escherichia coli. Protein Expr Purif. 2001;21(2): 317-22.

24. Boulanger MJ, Chow DC, Brevnova EE, Garcia KC. Hexameric structure and assembly of the interleukin-6/IL-6 alpha-receptor/ gp130 complex. Science. 2003;300(5628):2101-4.

25. Chow D, He X, Snow AL, Rose-John S, Garcia KC. Structure of an extracellular gp130 cytokine receptor signaling complex. Science. 2001; 291(5511):2150-5.

26. Tamada T, Honjo E, Maeda Y, Okamoto T, Ishibashi M, Tokunaga $M$, Kuroki R. Homodimeric cross-over structure of the human granulocyte colony-stimulating factor (GCSF) receptor signaling complex. Proc Natl Acad Sci USA. 2006;103(9):3135-40.

27. Krantz SB. Erythropoietin. Blood. 1991;77(3):419-34.

28. Wu H, Liu X, Jaenisch R, Lodish HF. Generation of committed erythroid BFU-E and CFU-E progenitors does not require erythropoietin or the erythropoietin receptor. Cell. 1995;83(1):59-67.

29. Brines M, Grasso G, Fiordaliso F, Sfacteria A, Ghezzi P, Fratelli M, Latini R, Xie QW, Smart J, Su-Rick CJ, Pobre E, Diaz D, Gomez D, Hand C, Coleman T, Cerami A. Erythropoietin mediates tissue protection through an erythropoietin and common betasubunit heteroreceptor. Proc Natl Acad Sci USA. 2004;101(41): 14907-12.

30. Arcasoy MO. The non-haematopoietic biological effects of erythropoietin. Br J Haematol. 2008;141(1): 14-31.

31. Yoshimura A, Longmore G, Lodish HF. Point mutation in the exoplasmic domain of the erythropoietin receptor resulting in hormone-independent activation and tumorigenicity. Nature. 1990; 348(630):647-9.

32. Elliott S, Lorenzini T, Yanagihara D, Chang D, Elliott G. Activation of the erythropoietin (EPO) receptor by bivalent anti-EPO receptor antibodies. J Biol Chem. 1996;271(40):24691-7.

33. Wrighton NC, Farrell FX, Chang R, Kashyap AK, Barbone FP, Mulcahy LS, Johnson DL, Barrett RW, Jolliffe LK, Dower WJ. Small peptides as potent mimetics of the protein hormone erythropoietin. Science. 1996; 273(5274):458-64.

34. Seubert N, Royer Y, Staerk J, Kubatzky KF, Moucadel V, Krishnakumar S, Smith SO, Constantinescu SN. Active and inactive orientations of the transmembrane and cytosolic domains of the erythropoietin receptor dimer. Mol Cell. 2003;12(5):1239-50.

35. Livnah O, Stura EA, Middleton SA, Johnson DL, Jolliffe LK, Wilson IA. Crystallographic evidence for preformed dimers of erythropoietin receptor before ligand activation. Science. 1999; 283 (5404):987-90.

36. Cheetham JC, Smith DM, Aoki KH, Stevenson JL, Hoeffel TJ, Syed RS, Egrie J, Harvey TS. NMR structure of human erythropoietin and a comparison with its receptor bound conformation. Nat Struct Biol. 1998; 5(10):861-6.

37. Zhan H, Liu B, Reid SW, Aoki KH, Li C, Syed RS, Karkaria C, Koe $G$, Sitney K, Hayenga K, Mistry F, Savel L, Dreyer M, Katz $B A$, Schreurs J, Matthews DJ, Cheetham JC, Egrie J, Giebel LB, Stroud RM. Engineering a soluble extracellular erythropoietin receptor (EPObp) in Pichia pastoris to eliminate microheteroge- 
neity, and its complex with erythropoietin. Protein Eng. 1999; 12(6):505-13.

38. Constantinescu SN, Keren T, Socolovsky M, Nam H, Henis YI, Lodish HF. Ligand-independent oligomerization of cell-surface erythropoietin receptor is mediated by the transmembrane domain. Proc Natl Acad Sci U S A. 2001; 98(8):4379-84.

39. Remy I, Wilson IA, Michnick SW. Erythropoietin receptor activation by a ligand-induced conformation change. Science. 1999; 283(5404):990-3.

40. Philo JS, Aoki KH, Arakawa T, Narhi LO, Wen J. Dimerization of the extracellular domain of the erythropoietin (EPO) receptor by EPO: one high-affinity and one low-affinity interaction. Biochemistry. 1996;35(5):1681-91.

41. Lok S, Kaushansky K, Holly RD, Kuijper JL, Lofton-Day CE, Oort PJ, Grant FJ, Heipel MD, Burkhead SK, Kramer JM, et al. Cloning and expression of murine thrombopoietin cDNA and stimulation of platelet production in vivo. Nature. 1994;369 (6481): $565-8$.

42. de Sauvage FJ, Hass PE, Spencer SD, Malloy BE, Gurney AL, Spencer SA, Darbonne WC, Henzel WJ, Wong SC, Kuang WJ, et al. Stimulation of megakaryocytopoiesis and thrombopoiesis by the c-Mpl ligand. Nature. 1994;369(6481):533-8.

43. Drachman JG, Griffin JD, Kaushansky K. The c-Mpl ligand (thrombopoietin) stimulates tyrosine phosphorylation of Jak2, Shc, and c-Mpl. J Biol Chem. 1995;270(10):4979-82.

44. Rouyez MC, Boucheron C, Gisselbrecht S, Dusanter-Fourt I, Porteu F. Control of thrombopoietin-induced megakaryocytic differentiation by the mitogen-activated protein kinase pathway. Mol Cell Biol. 1997;17(9):4991-5000.

45. Kaushansky $K$. The mpl ligand: molecular and cellular biology of the critical regulator of megakaryocyte development. Stem Cells. 1994; 12 Suppl 1:91-6.

46. Solar GP, Kerr WG, Zeigler FC, Hess D, Donahue C, de Sauvage FJ, Eaton DL. Role of c-mpl in early hematopoiesis. Blood. 1998;92(1):4-10.

47. Sabath DF, Kaushansky K, Broudy VC. Deletion of the extracellular membrane-distal cytokine receptor homology module of
Mpl results in constitutive cell growth and loss of thrombopoietin binding. Blood. 1999;94(1):365-7.

48. Feese MD, Tamada T, Kato Y, Maeda Y, Hirose M, Matsukura Y, Shigematsu H, Muto T, Matsumoto A, Watarai H, Ogami K, Tahara T, Kato T, Miyazaki H, Kuroki R. Structure of the receptor-binding domain of human thrombopoietin determined by complexation with a neutralizing antibody fragment. Proc Natl Acad Sci USA. 2004;101(7):1816-21.

49. Matthews EE, Thevenin D, Rogers JM, Gotow L, Lira PD, Reiter $L A$, Brissette WH, Engelman DM. Thrombopoietin receptor activation: transmembrane helix dimerization, rotation, and allosteric modulation. FASEB J. 2011;25(7):2234-44.

50. Defour JP, Itaya M, Gryshkova V, Brett IC, Pecquet C, Sato T, Smith SO, Constantinescu SN. Tryptophan at the transmembrane-cytosolic junction modulates thrombopoietin receptor dimerization and activation. Proc Natl Acad Sci USA. 2013;110(7): 2540-5.

51. Constantinescu $S N$, Keren T, Russ WP, Ubarretxena-Belandia I, Malka Y, Kubatzky KF, Engelman DM, Lodish HF, Henis YI. The erythropoietin receptor transmembrane domain mediates complex formation with viral anemic and polycythemic gp55 proteins. J Biol Chem. 2003;278(44):43755-63.

52. Ebie AZ, Fleming $K G$. Dimerization of the erythropoietin receptor transmembrane domain in micelles. J Mol Biol. 2007; 366(2): $517-24$.

53. Ding J, Komatsu H, Iida S, Yano H, Kusumoto S, Inagaki A, Mori F, Ri M, Ito A, Wakita A, Ishida T, Nitta M, Ueda R. The Asn505 mutation of the $c-M P L$ gene, which causes familial essential thrombocythemia, induces autonomous homodimerization of the c-Mpl protein due to strong amino acid polarity. Blood. 2009; 114(15):3325-8. 